\title{
PEMANFAATAN LIMBAH DAPUR SEGAR MENJADIBERBAGAI PRODUK KOMERSIAL BAGI IBU RUMAH TANGGA DI WILAYAH RAWAMANGUN
}

\author{
Yati Setiati ${ }^{1)}$, Nurlaila $^{2)}$ \\ Program Studi Tata Boga, Jurusan Ilmu Kesejahteraan Keluarga \\ Fakultas Teknik, Universitas Negeri Jakarta \\ setiati.yati@yahoo.co.id
}

\begin{abstract}
ABSTRAK
Pengabdian pada masyarakat ini bertujuan untuk mengaktifkan ibu-ibu rumah tangga di Kelurahan Rawamangun, membekali pengetahuan dan keterampilan dalam penanganan limbah dapur segar menjadi berbagai produk komersial. Dalam pelatihan ini diharapkan dapat meningkatkan keterampilan ibu-ibu rumah tangga yang pada akhirnya dapat menambah pendapatankeluarga. Khalayak sasaran yang strategis yaitu ibu-ibu rumah tangga yang tidak mempunyai pekerjaan. Dengan kriteria latar belakang ekonomi mereka adalah menengah ke bawah. Dengan diajarkan keterampilan membuat manisan dari limbah dapur segar diharapkan dapat mengatasi pengeluaran keuangan keluarga.

Pada pelaksanaannya, kegiatan ini diikuti oleh sekitar 35 orang peserta dari kelurahan Rawamangun Jakarta Timur. Kegiatan pengabdian masyarakat di Kelurahan rawamangun diawali dengan pengurusan izin lokasi kepada Ketua Program Studi Tata Boga Universitas Negeri Jakarta, selanjutnya pendataan calon peserta yang terdiri dari Kader PKK dan ibu-ibu rumah tangga. Kegiatan persiapan pengabdian dilakukan pada hari Kamis tanggal 4 September 2014 yaitu berupa proses penyiapan limbah dapur segar.

Pelaksanaan kegiatan dilakukan dengan metode ceramah, Tanya jawab dan demonstrasi, praktek serta diskusi langsung kepada peserta yang diakhiri dengan dilakukan analisis terhadap hasil kegiatan pelatihan. Berdasarkan hasil pemberian materi dan pelatihan pembuatan manisan basah yakni manisan basah buah tomat, manisan basah kulit buah semangka, manisan basah buah melon, manisan basah buah pepaya, manisan basah belimbing wuluh dari limbah sari belimbing wuluh. Manisan kering yakni manisan kering kulit buah melon, manisan kering kulit buah tomat. Serta sirup belimbing wuluh, maka dapat disimpulkan bahwa materi pelatihan yang diberikan sangat menarik minat peserta sehingga membuat para peserta sangat antusias mengikuti kegiatan.
\end{abstract}

Kata Kunci : Limbah Dapur Segar, Produk Komersial, Ibu Rumah Tangga di Wilayah Rawamangun

\section{PENDAHULUAN}

Jakarta Timur merupakan kota administrative dengan luas $187,75 \mathrm{~km}$ dengan populasi 2,693.896, yang terdiri dari 65 kelurahan, diantaranya kelurahan Rawamangun. Rawa-mangun terletak berbatasan dengan Kelurahan Kayu Putih di sebelah Selatan, Kelurahan Jati di sebelah Utara, Kelurahan Pisangan Lama di sebelahTimur, dan Kelurahan Utan Kayu di sebelah Barat.

Peningkatan kualitas keluarga merupakan tanggungjawab setiap keluarga. Peran ibu rumahtangga besar sekali artinya terutama dalam mengelola sumber keluarga. Dalam kehidupan sehari-harinya, ibu rumah tangga selalu menyiapkan hidangan untuk keluarganya. Memasak hidangan bahan pokok, lauk pauk hewani, sayuran dan kue-kue atau buah-buahan. Pekerjaan sehari-hari dalam rumah tangga seperti mengolah bahan makanan, menyisakan limbah sisa pengolahan dari bahan sumber protein hewani seperti ikan, ayam, udang dan sebagainya, juga dari bahan sayuran seperti tangkai bayam, kulit wortel, tangkai kangkung dan sebagainya. Limbah tersebut dinamakan limbah dapur segar. Limbah dapur bila dibiarkan begitu saja akan menyebabkan pencemaran lingkungan, mengeluarkan bau tidak sedap, memicu hewan pengerat seperti tikus, lalat, dan lain-lain serta 
dapat menimbulkan penyakit pes dan lain-lain. Dari buah-buahan seperti kulit yang tidak terpakai atau terbuang.

Limbah dapur adalah limbah yang berasal dari sisa bahan makanan yang akandiolah. Ada dua jenis limbah yaitu Limbah basah dan limbah kering. Limbah basah adalah limbah yang mudah membusuk seperti kulit pepaya, kulit semangka, kulit pisang dan lain-lain, Limbah tersebut dapat diolah berbagai produk makanan. Pengolahan aneka limbah dapur segar menjadi berbagai produk memberikan keuntungan tersendiri, selain memanfaatkan limbah segar, juga dapat dijadikan peluangusaha baru yang berpotensi penyerapan pangsa pasar yang cukup baik.

Oleh karena itu, pembelajaran pembuatan berbagai produk dari limbah dapur segar sangat berguna menjadi produk komersial bagi ibu-ibu rumah tangga untuk menambah penghasilan keluarga. Hal ini sangat diharapkan untuk memberikan motivasi dan solusi dalam mengatasi permasalahan perekonomian keluarga dan masyarakat.

Pengabdian pada masyarakat ini bertujuan untuk mengaktifkan ibu-ibu rumah tangga di Kelurahan Rawamangun, membekali pengetahuan dan keterampilan limbah dapur segar menjadi berbagai produk komersial. Dalampelatihan ini diharapkan dapat meningkatkan keterampilan ibu-ibu rumahtangga yang pada akhirnya dapat menambah pendapatan keluarga.

\section{METODE PENELITIAN}

Berdasarkan kajian teoritis diketahui bahwa limbah dapur basah mengandung berbagai kandungan gizi yaitu karbohidrat, protein, amilum, vitamin, dan mineral.Jumlah limbah yang banyak pada setiap keluarga, perlu dilakukan penanganan limbah menjadi produk olahan yang bermanfaat untuk menambah penghasilan keluarga. Biasanya timbul masalah bagaimana menangani limbah dapur segar agar dapat dibuatproduk, dijual dengan harga murah tetapi menarik perhatian keluarga. Olehkarenaitu, untuk mengatasi masalah tersebut diberikan pengajaran tentang membuat manisan, dan lain-lain dari limbah dapur segar, selain itu keterampilan yang di dapat dapat dijadikan peluang usaha bagi ibuibu untuk menambah pendapatan keluarga.

Kaitan dengan masalah yang akan dipecahkan dalam kegiatan ini adalah langkah- langkah secara eksternal dengan situasi yang meliputi:

e. Penyuluhan, yang bertujuan untuk meningkatkan pengetahuan tentang pemanfaatan limbah dapur segar menjadi berbagai produk komersial bagi peserta, yaitu ibu rumah tangga di wilayah rawamangun.

f. Pelatihan, yaitu dengan cara mendemonstrasikan dan menginstruksikan salah satu peserta dalam membuat beberapa resep manisanbasah, manisankeringdansirupdarilimbahdapurse

gar untuk meningkatkan keterampilan dalam mengolah aneka variasi produk pemanfaatan limbah dapur segar.

g. Evaluasi, setelah diberikan penyuluhan dan pelatihan, diharapkan pengetahuan peserta tentang manisanbasah, manisan kering dan sirup dari limbah dapur segar meningkat.

Khalayak sasaran yang strategi syaitu ibuibu rumah tangga yang tidak mempunyai pekerjaan. Dengan kriteria latar belakang ekonomi mereka adalah menengah kebawah dengan diajarkan keterampilan membuat manisan dari limbah dapur segar diharapkan dapat mengatasi pengeluaran keuangan keluarga.Pada pelaksanaannya, kegiatan ini diikuti oleh sekitar 35 orang peserta dari kelurahan Rawamangun Jakarta Timur. Hal ini dikarenakan kegiatan ini merupakan salah satu kegiatan pembelajaran yang cukup menarik bagi ibu-ibu lingkungan sekitar merupakan kegiatan yang dapat diteruskan sebagai penyuluhan yang dapat disampaikan untuk warga setempat termasuk pengetahuan dan keterampilan dalam membuat produk komersial dalam pemanfaatan limbah dapur segar seperti manisan basah, manisan kering dan sirup.

\section{Keterkaitan}

Pengabdian Kepada Masyarakat merupakan kegiatan Tri Dharma Perguruan Tinggi yang dilaksanakan oleh dosen-dosen Universitas Negeri Jakarta. Pelaksanaan ini dilaksanakan di Kelurahan Rawamangunyang sebagian besar warganya tergolong ekonomi lemah dan ibu-ibu rumah tangganya tidak bekerja dan membutuhkan pelatihan agar dapat dimanfaatkan keluarga sebagai bahan untuk berwirausaha membuat manisan basah dan kering dari limbah dapur segar mereka sendiri. 
Metode yang diterapkan dalam kegiatan ini adalah ceramah tentang pemanfaatan limbah dapur segar menjadi berbagai produk komersial bagi di ibu rumah tangga di wilayah rawamangun, pemberian materi dan resepresep produk manisan dan sirup kepada khalayak sasaran untuk memperkaya pengetahuan mereka, serta pelatihan mengolah aneka produk pemanfaatan limbah dapur segar dengan mendemonstrasikan dan mempraktekan beberapa macam manisan.

\section{HASIL DAN PEMBAHASAN}

Berdasarkan kajian teoritis bahwa limbah dapur baik limbah basah maupun limbah kering dapat diolah menjadi produk komersial yang dapat menambah penghasilan keluarga.limbah dapur mengandung berbagai kandungan gizi yaitu karbohidrat, protein, amilum, vitamin, dan mineral.

Kegiatan pengabdian masyarakat di Kelurahan rawamangun diawali dengan pengurusan izin lokasi kepada Ketua Program Studi Tata Boga Universitas Negeri Jakarta, selanjutnya pendataan calon peserta yang terdiri dari Kader PKK dan ibu-ibu rumah tangga. Kegiatan persiapan pengabdian dilakukan pada hari Kamis tanggal 4 September 2014 yang diikutioleh 35 orang peserta yaitu berupa proses penyiapan limbah dapur. Pelaksanaan kegiatan dilakukan dengan metode ceramah, Tanya jawab dan demonstrasi, praktek serta diskusi langsung kepada peserta yang diakhiri dengan dilakukan analisis terhadap hasil kegiatan pelatihan.

Kegiatan pengabdian kepada masyarakat ini diikuti oleh Ibu-Iburumah tangga yang tinggal di lingkungan kelurahan Rawamangun Jakarta Timur sehingga dapat mengetahui tentang limbah dapu rsegar dan meningkatkan keterampilan dalam pemanfaatan limbah dapur segar untuk dijadikan produk komersial seperti manisan basah, manisan kering dan sirup. Diharapkan setelah mengikuti kegiatan ini pengetahuan dan keterampilan dapat menjadi lebih baik.

Berdasarkan hasil penyuluhan/pemberian materi tentang pemanfaatan limbah dapur segar sebagai produk komersial bagi ibu-ibu rawamangun dan pelatihan pembuatan manisan basah, manisan kering dan sirup yang diikuti oleh 35 orang peserta, maka dapat disimpulkan bahwa materi pelatihan yang diberikan sangat menarik minat peserta sehingga membuat para peserta sangat antusias mengikuti kegiatan.

\section{KESIMPULAN}

Kegiatan pelatihan pengabdian masyarakat telah dilakukan dan menunjukkan hasil terjadinya pening-katan keterampilan peserta dalam membuat aneka produk yang berasal dari limbah dapur. Berbagai teknik yang dilakukan dalam pembuatan aneka produk yang berasal dari limbah dapur yaitu teknik penggulaan. Teknik penggulaan adalah cara mengawetkan bahan/limbah segar dengan meng-gunakan gula. Produknya seperti sirup, manisan basah, manisan kering, selai, sari buah, dan lain-lain.

Kegiatan pengabdian masyarakat di Kelurahanrawamangun diawali dengan pengurusan izin lokasi kepada Ketua Program Studi Tata Boga Universitas Negeri Jakarta, selanjutnya pendataan calon peserta yang terdiri dari Kader PKK dan ibu-iburumah tangga.Kegiatan persiapan pengabdian dilakukan pada hari Kamis tanggal 4 September 2014 yaituberupa proses penyiapan limbah dapur. Pelaksanaan kegiatan dilakukan dengan metode ceramah, Tanya jawab dan demonstrasi, praktek serta diskusi langsung kepada peserta yang diakhiri dengan dilakukan analisis terhadap hasil kegiatan pelatihan.

Berdasarkan hasil penyuluhan/ pemberian materi tentang pemanfaatan limbah dapur segar sebagai produk komersial bagi ibu-ibu rawamangun dan pelatihan pembuatan manisan basah, manisan kering dan sirup yang diikuti oleh 35 orang peserta, maka dapat disimpulkan bahwa materi pelatihan yang diberikan sangat menarik minat peserta sehingga membuat para peserta sangat antusias mengikuti kegiatan. Dikarenakan kegiatan ini sangat bermanfaat, disarankan untuk melakukan kegiatan serupa secara berkala dan bekelanjutan.

\section{DAFTAR PUSTAKA}

[1] Tietze, Harald. 2002. Terapi Pepaya. Jakarta: Prestasi Pustaka Publishers. Cetakan pertama.

[2] Deptan. Pentingnya tanaman pepaya bagi kesehatan. Koran Tempo 
[3] Setiati Yati, RahayuSuci, Istiany Ari, ModulPengawetanMakanan. UNJ

[4] SetiatiYati, Ridawati. 2013. RPKPS TeknologiPengolahanHewanidanNabati, UNJ.
[5] Sumartono. 1982. Bercocok Tanam Pisang. Jakarta : offset Bumirestu.

[6] Winarno, DasarPengawetanMakanan, Jakarta. 